\title{
Perkembangan Terapi Sistemik pada Pruritus
}

\author{
Melody Febriana Andardewi, Windy Keumala Budianti, Lili Legiawati, Yudo Irawan
}

\author{
Departemen Dermatologi dan Venereologi Fakultas Kedokteran Universitas Indonesia \\ RSUPN dr. Cipto Mangunkusumo Jakarta, Indonesia \\ Alamat Korespondensi: melodyfebriana@gmail.com
}

\begin{abstract}
Abstrak
Pruritus merupakan sensasi tidak nyaman yang mencetuskan keinginan untuk menggaruk. Sensasi tersebut disebabkan oleh berbagai hal, misalnya penyakit kulit, penyakit sistemik, atau idiopatik, gangguan psikiatri, serta penyakit neurologis. Pruritus menjadi masalah kesehatan karena dapat memberi dampak negatif terhadap kualitas hidup pasien. Pendekatan tata laksana pruritus diberikan secara bertingkat mulai dari terapi dasar, terapi target, dan terapi simtomatik. Pada kasus pruritus kronik yang refrakter maupun pruritus tanpa sebab yang diketahui, terapi simtomatik berperan besar dan dapat diberikan pada pasien tersebut. Tata laksana pada pruritus kronik saat ini banyak diteliti seiring dengan ditemukan berbagai mekanisme yang mendasari terjadinya pruritus. Sesuai dengan patofisiologi dari pruritus, terapi sistemik yang dikembangkan menargetkan pada reseptor spesifik di sistem saraf dan sistem imunitas yang berperan pada jalur sinyal pruritus. Berbagai terapi terbaru yang masih diteliti dalam uji klinis menunjukkan hasil yang menjanjikan dan berpotensi menjadi pilihan terapi pada pasien dengan pruritus kronik.
\end{abstract}

Kata Kunci: panduan terapi, pruritus, terapi terkini

\section{Current Systemic Therapy for Pruritus}

\begin{abstract}
Pruritus is an unpleasant sensation that triggers the desire to scratch. It can be associated with various conditions such as skin or systemic diseases, idiopathic disorders, psychiatric disorders, and neurological diseases. Pruritus becomes a health problem considering it caused a negative impact on the patient's quality of life. The therapeutic approach for pruritus is given stepwise, starting from basic therapy, targeted therapy, and symptomatic therapy. Symptomatic therapy has a major impact and could be given to patients with chronic refractory pruritus or pruritus of unknown origin. The management of chronic pruritus is currently being studied in line with the discovery of many mechanisms underlying pruritus. In accordance with the pathophysiology of pruritus, systemic therapy is developed for specific receptors at the nervous and immune system that plays a role in the pruritus signaling pathway. Novel therapies are still being investigated in clinical trials and have shown promising results, thus could be the treatment options for patients with chronic pruritus.
\end{abstract}

Keywords: guideline therapy, novel therapy, pruritus

\section{Pendahuluan}

Gatal atau pruritus merupakan sensasi tidak nyaman yang mendorong seseorang untuk menggaruk. ${ }^{1}$ Pruritus menjadi masalah yang penting karena dapat menimbulkan penurunan kualitas hidup pasien serta sering mengalami kekambuhan terutama bila kronik (terjadi selama 6 minggu atau lebih). ${ }^{1,2}$ Prevalensi pruritus kronik secara umum bervariasi dengan rentang sebesar $13 \%$ hingga $38 \% .{ }^{3}$ Khusus pada populasi geriatri, prevalensi pruritus mencapai $7 \%$ hingga $37,5 \% .^{3}$
Pruritus dapat terjadi pada penyakit kulit, penyakit sistemik, akibat garukan kronis, maupun idiopatik. Terapi pruritus saat ini belum memuaskan sehingga membuahkan perkembangan berbagai studi mengenai efektivitas terapi sistemik baru. Tinjauan pustaka ini membahas mengenai berbagai pengobatan sistemik terkini pada pruritus.

\section{Etiopatofisiologi Pruritus}

Pruritus timbul akibat interaksi kompleks antara kulit, sistem imunitas, dan sistem saraf. 
Pruritogen akan berikatan dengan reseptor di ujung bebas serabut saraf $\mathrm{C}$ tak bermielin di kulit. ${ }^{4}$ Sensasi gatal diinduksi melalui aktivasi oleh pruritogen pada $G$ protein-coupled receptors (GPCR). ${ }^{5,6}$ Berbagai GPCR yang diketahui berkontribusi pada pruritus adalah reseptor histamin-1, protease-activated receptors (PAR)-2 dan PAR-4, mas-related $G$ protein-coupled receptor (mrgpR), dan sebagainya. ${ }^{5,7}$ Ikatan antara pruritogen dan GPCR dapat mengaktivasi berbagai kanal ion yaitu transient receptor potential vanilloid 1 (TRPV1), transient receptor potential ankyrin 1 (TRPA1), serta voltage-gated sodium channels $\left(\mathrm{Na}_{\mathrm{v}}\right)$ (Gambar 1). ${ }^{5,7}$ Berbagai pruritogen beserta reseptor yang berperan tercantum pada tabel 1.

Tabel 1. Berbagai Pruritogen Beserta Reseptor ${ }^{5}$

\begin{tabular}{|c|c|c|}
\hline Kategori & Pruritogen & Reseptor \\
\hline \multirow[t]{2}{*}{ Amine } & Histamin & Reseptor H1/H4 \\
\hline & Serotonin & Reseptor 5-hydroxytriptamine $\left(5-\mathrm{HT}_{2}\right)$ \\
\hline Protease & $\begin{array}{l}\text { Kallikrein, tryptase, trypsin, cathepsin } S, \\
\text { protease eksogen }\end{array}$ & $\begin{array}{l}\text { Protease-activated reseptor (PAR- } \\
\text { 2/PAR- } 4 \text { ) }\end{array}$ \\
\hline \multirow[t]{4}{*}{ Neuropeptida } & Substansi P & Reseptor neurokinin-1 \\
\hline & Endothelin-1 & Reseptor endothelin A (ETA) \\
\hline & Nerve growth factor & Tropomyosin receptor kinase A (TrkA) \\
\hline & Opioid & Reseptor $\mu$-opioid/ $\kappa$-opioid \\
\hline \multirow[t]{2}{*}{ Mediator lipid } & Platelet-activating factor (PAF) & Reseptor PAF \\
\hline & Lysophosphatidic acid (LPA) & Reseptor LPA5 \\
\hline \multirow[t]{4}{*}{ Sitokin } & IL-4/13 & IL-4R $\alpha$ \\
\hline & IL-31 & IL-31RA/reseptor onkostatin M \\
\hline & Thymic stromal lymphopoietin (TSLP) & Reseptor TSLP \\
\hline & IL-17 & IL-17RA-C \\
\hline Agonis mgpr & Klorokuin & MrgprX \\
\hline $\begin{array}{l}\text { Tidak } \\
\text { terkategorisasi }\end{array}$ & Asam empedu & Takeda G-protein receptor 5 (TGR5) \\
\hline
\end{tabular}

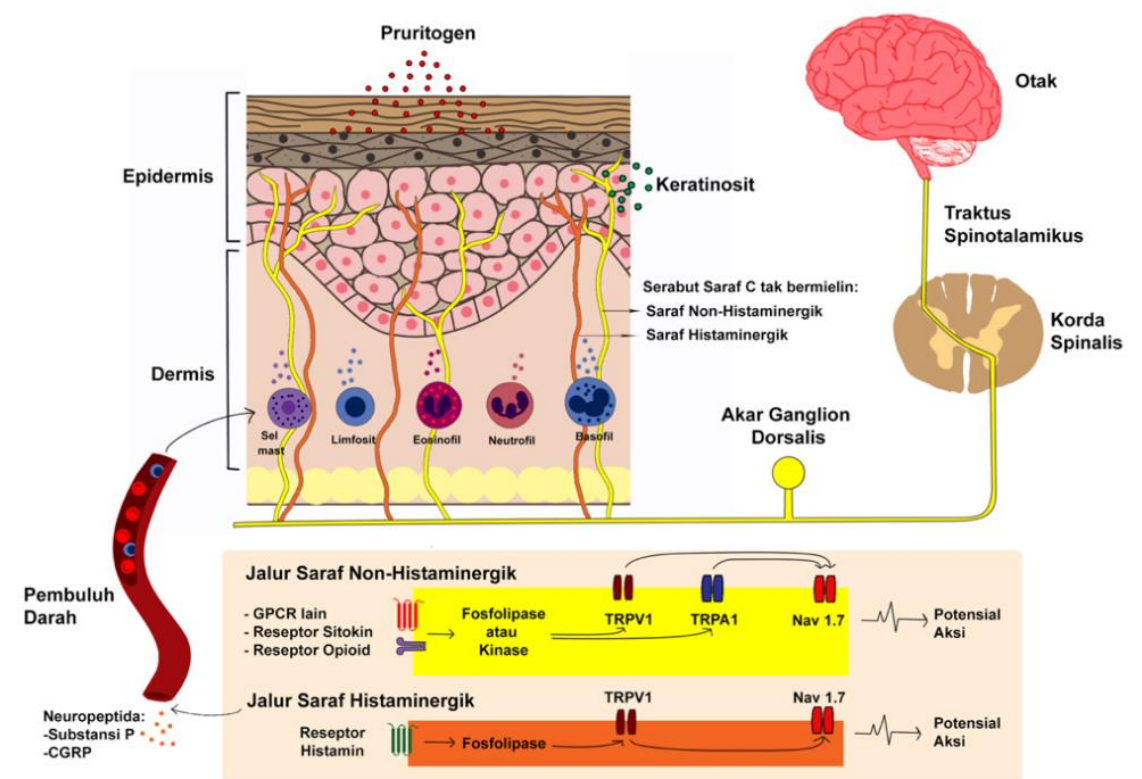

Gambar 1. Jalur Sinyal Pruritus. ${ }^{5}$ Keterangan: GPCR: G-protein coupled receptor; TRPV1: transient receptor potential vanilloid 1; TRPA1: transient receptor potential ankyrin 1; $\mathrm{Na}_{\mathrm{v}} 1.7$ : voltage-gated sodium channel 1.7; CGRP: calcitonin gene-related protein. (Gambar dimodifikasi dari Kepustakaan No. 5)

Serabut saraf $\mathrm{C}$ diklasifikasikan menjadi dua subgrup yaitu $C$ mechano-insensitive afferences
$\left(\mathrm{C}_{\mathrm{MIA}}\right)$ dan $C$ mechano-heat sensitive $(\mathrm{CMH}){ }^{7}$ Jalur sinyal pruritus histaminergik diperankan oleh 
$\mathrm{C}_{\text {MIA }}$ dan diaktivasi oleh histamin. ${ }^{7,8}$ Sedangkan jalur sinyal pruritus non-histaminergik terdapat pada $\mathrm{CMH}$ dan diaktivasi oleh protease, sitokin, kemokin, dan amin. ${ }^{4}$ Berbagai sitokin yang berperan pada pruritus contohnya interleukin (IL)4, IL-13, IL-31, IL-17, serta thymic stromal lymphopoietin (TSLP). ${ }^{5}$ Reseptor histamin-1 diekspresikan pada $\mathrm{C}_{\mathrm{MIA}}$, sedangkan pada $\mathrm{CMH}$ terdapat berbagai reseptor lain. ${ }^{7}$

Pada pruritus akut, histamin berperan penting sebagai mediator gatal. Histamin dilepaskan secara utama oleh sel mast, namun juga dapat dilepaskan oleh sel basofil. Histamin berikatan dengan reseptor histamin di saraf dan mengaktivasi TRPV1 sehingga terjadi potensial aksi. ${ }^{5}$ Potensial aksi menyebabkan pelepasan neuropeptida (substansi $\mathrm{P}$ dan calcitonin gene-related protein), kemudian mencetuskan inflamasi neurogenik. ${ }^{5}$ Substansi P, termasuk dalam famili tachykinin, merupakan neuropeptida yang dilepaskan oleh neuron peptidergik dan memiliki afinitas tinggi pada reseptor neurokinin-1 (NK-1). ${ }^{9}$ Pada pruritus kronik, aktivasi GPCR oleh pruritogen nonhistamin memicu terbukanya kanal ion TRPV1 dan TRPA1 melalui sistem fosfolipase atau kinase. ${ }^{4}$ Selanjutnya, terjadi aktivasi $\mathrm{Na}_{\mathrm{v}} 1.7$ dan memicu potensial aksi. ${ }^{4}$ Sensasi gatal yang ditransmisikan oleh serabut saraf $\mathrm{C}$ bersinaps pada korda spinalis dan selanjutnya ditransmisikan melalui traktus spinotalamikus menuju ke otak. ${ }^{10}$

International Forum for the Study of Itch (IFSI) pada tahun 2007 membuat klasifikasi pruritus menjadi tiga grup kategori klinis, yaitu grup I pada penyakit kulit; grup II tanpa penyakit kulit; dan grup III akibat lesi garukan kronik. ${ }^{1,2}$ Pruritus dapat dikategorikan lebih lanjut sesuai dengan penyakit yang mendasari, yaitu penyakit dermatologi (kategori I), penyakit sistemik (kategori II), penyakit neurologis (kategori III), psikogenik (kategori IV), campuran (kategori V), dan lain-lain (kategori VI). ${ }^{1,2}$

\section{Prinsip Tata Laksana Pruritus}

Pendekatan tata laksana pruritus diberikan secara bertahap, yaitu terapi dasar, terapi target, dan simtomatik. ${ }^{7}$ Langkah pertama dalam tata laksana pruritus adalah terapi dasar berupa perawatan kulit untuk menjaga hidrasi kulit, menghindari faktor pencetus gatal, serta memutus siklus gatal-garuk. ${ }^{7,11}$ Evaluasi kondisi pasien secara cermat dilakukan untuk menentukan penyebab primer pruritus agar terapi target dapat diberikan sesuai etiologi. ${ }^{11,12}$ Bila etiologi pruritus tidak diketahui atau terjadi kegagalan terapi, diperlukan terapi simtomatik yaitu menggunakan terapi topikal atau terapi sistemik yang menargetkan sistem saraf atau sistem imunitas. ${ }^{7,11}$

\section{Terapi Pruritus dengan Target Sistem Imunitas}

Terapi sistemik konvensional untuk pruritus menggunakan antihistamin, kortikosteroid sistemik, serta imunosupresan. Beberapa modalitas terapi lain meliputi inhibitor PDE-4, antagonis interleukin, inhibitor janus kinase, serta antagonis imunoglobulin E. ${ }^{10}$

\section{Antihistamin (Level of Evidence (LoE) 1)}

Antihistamin memiliki efikasi terbatas pada pruritus kronik, tetapi penggunaan antihistamin H1 (AH1) baik golongan sedatif maupun non-sedatif disarankan untuk terapi awal pruritus kronik. ${ }^{11}$ Golongan AH1 generasi kedua dapat mengurangi pruritus secara efektif pada penyakit yang berkaitan dengan peningkatan degranulasi sel mast sehingga direkomendasikan pada pruritus akibat urtikaria kronik spontan dan mastositosis. ${ }^{11}$ Dosis dapat ditingkatkan hingga empat kali. ${ }^{11}$ Berdasarkan meta-analisis yang membandingkan berbagai AH1 generasi ke-2 pada urtikaria kronik spontan, bilastine memiliki nilai standardized mean difference (SMD) untuk perubahan skor pruritus dari baseline sebesar -0,57. Skor SMD terbesar didapatkan pada olopatadine dan rupatidine. Sedangkan, levocetirizine, desloratadine, fexofenadine, dan cetirizine secara berurutan memiliki nilai SMD yang lebih rendah dibandingkan bilastine. ${ }^{13}$

Reseptor histamin H3 dan H4 dilaporkan terlibat pada pruritus. $\mathrm{H} 4$ secara khusus dikaitkan dengan fungsi sel mast, sel $\mathrm{T}$, sel dendritik, monosit, dan eosinofil. ${ }^{11}$ Pada uji klinis fase 2, antagonis reseptor $\mathrm{H} 4$ menurunkan gejala gatal secara signifikan pasien dermatitis atopik derajat ringan-sedang. ${ }^{14}$ 
Tabel 2. Klasifikasi antihistamin $\mathbf{H 1}{ }^{15}$

\begin{tabular}{|c|c|c|}
\hline & Generasi Pertama & Generasi Kedua \\
\hline Alkilamin & $\begin{array}{l}\text { Klorfeniramin, feniramin, klemastin, } \\
\text { siproheptadin, difenhidramin, prometazin, } \\
\text { hidroksizin }\end{array}$ & Acrivastine \\
\hline Piperazin & Hidroksizin & Cetirizine, levocetirizine \\
\hline Piperidin & Siproheptadin, ketotifen & $\begin{array}{l}\text { Astemizole, desloratadine, fexofenadine, } \\
\text { loratadine, mizolastine, olopatadine, } \\
\text { terfenadine, bilastine }\end{array}$ \\
\hline Etanolamin & Dimenhidrinat, difenhidramin, doksilamin & \\
\hline Fenotiazin & Prometazin & \\
\hline Lain-lain & Doksepin & Azelastine \\
\hline
\end{tabular}

\section{Kortikosteroid Sistemik (LoE 1)}

Kortikosteroid memiliki efek anti-inflamasi dan imunosupresi. ${ }^{16}$ Meskipun tidak secara langsung bekerja sebagai antipruritus, kortikosteroid dapat menurunkan gejala pruritus dengan cara mereduksi kadar sitokin, misalnya IL31.,16 Kadar IL-31 meningkat pada berbagai penyakit kulit contohnya pada dermatitis atopik, prurigo nodularis, dermatitis kontak alergi, psoriasis, dan cutaneous T-cell lymphoma. ${ }^{6,17}$

Penggunaan kortikosteroid oral jangka pendek dapat menjadi metode efektif untuk menekan flares dari penyakit inflamasi kulit berat serta dapat menurunkan gejala gatal. ${ }^{16}$ Dosis prednison yaitu 2,5 mg hingga $100 \mathrm{mg}$, dengan dosis awal $30 \mathrm{mg}$ hingga $40 \mathrm{mg}$ per hari. ${ }^{11}$ Metilprednisolon intravena dengan dosis 0,5 gram hingga 1 gram per hari memiliki potensi tinggi dengan aktivitas mineralokortikoid yang rendah. ${ }^{11}$ Terapi kortikosteroid sistemik jangka panjang dapat mencetuskan supresi sumbu hipotalamus-pituitariadrenal (HPA axis), hipertensi, hiperglikemia, osteoporosis, serta miopati. ${ }^{16}$

\section{Imunosupresan}

\section{a. Metotreksat (LoE 1)}

Metotreksat (MTX) merupakan antagonis asam folat yang bekerja dengan cara menginhibisi dihydrofolate reductase, inhibisi sintesis purin, serta menurunkan proliferasi sel $\mathrm{T}^{16}$ Obat golongan antimetabolit ini dilaporkan bermanfaat dalam mengurangi gatal pada pasien psoriasis, dermatitis atopik, dan prurigo nodularis yang refrakter terhadap terapi topikal. ${ }^{11,18}$ Dosis MTX sebesar $5 \mathrm{mg}$ hingga $25 \mathrm{mg}$ per minggu dilaporkan dapat memperbaiki gejala gatal pada prurigo nodularis sebesar $91 \%$ di bulan ke-3 dan $94 \%$ di bulan ke-6. ${ }^{19,20}$ Efek samping obat yaitu hepatotoksisitas, mielosupresi, dan gangguan gastrointestinal. Obat MTX dikontraindikasikan pada kehamilan dan pada pasien yang ingin punya anak. Suplementasi dengan asam folat juga perlu diberikan pada pasien. ${ }^{16}$

\section{b. Siklosporin (LoE 1)}

Siklosporin merupakan inhibitor kalsineurin yang bekerja dengan cara inhibisi sinyal sel Th17. Siklosporin secara efektif mengurangi gatal pada psoriasis, dermatitis atopik, dan prurigo nodularis. ${ }^{11,18,21}$ Berdasarkan telaah kritis, lima uji klinis membuktikan siklosporin dosis $1,25 \mathrm{mg}$ hingga $5 \mathrm{mg} / \mathrm{kgBB} /$ hari dapat mengurangi gejala gatal secara signifikan pada pasien psoriasis. ${ }^{22}$ Hasil telaah kritis pada pasien dermatitis atopik, siklosporin 5 $\mathrm{mg} / \mathrm{kgBB} /$ hari memiliki efikasi yang tinggi terhadap perbaikan gatal, gejala klinis, serta kualitas hidup pasien dalam 4 bulan terapi dibandingkan dengan plasebo. ${ }^{21}$ Siklosporin 3 $\mathrm{mg}$ hingga $5 \mathrm{mg} / \mathrm{kgBB} / \mathrm{hari}$ pada pasien prurigo nodularis menunjukkan perbaikan lesi dan gejala gatal dalam 3 minggu terapi dengan efek maksimal terlihat rata-rata dalam 2 hingga 3 bulan. ${ }^{19}$ Siklosporin memiliki efek samping berupa nefrotoksisitas, hipertensi, serta peningkatan risiko kanker kulit dan keganasan internal. ${ }^{16,18}$

\section{c. Azatioprin (LoE 3)}

Azatioprin merupakan analog purin yang bekerja dengan cara inhibisi sintesis purin sehingga mencegah proliferasi sel $\mathrm{T}$ dan sel B. ${ }^{23}$ Azatioprin memiliki efikasi yang sama seperti MTX dalam memperbaiki keparahan lesi, gejala gatal, dan kualitas hidup pasien dermatitis atopik. $^{23}$ Pengobatan dengan azatioprin $25 \mathrm{mg}$ hingga $275 \mathrm{mg}$ pada pruritus kronik yang refrakter dapat menurunkan skala Visual Analog Scale (VAS) gatal dari 9,2 menjadi 1,6. ${ }^{11,24}$ Efek samping yang dilaporkan yaitu reaksi hipersensitivitas, peningkatan 
risiko kanker kulit, gangguan gastrointestinal, serta leukopenia. ${ }^{16}$

\section{Inhibitor Phosphodiesterase-4 (LoE 1)}

Apremilast merupakan inhibitor PDE4 oral yang telah disetujui untuk terapi psoriasis. Berdasarkan meta-analisis dari tiga uji klinis, apremilast $20 \mathrm{mg}$ hingga $30 \mathrm{mg}$ menurunkan skor pruritus secara signifikan pada pasien psoriasis tipe plak derajat sedang-berat dibandingkan dengan plasebo (mean difference -2,18; $\mathrm{p}<0,001$ ). ${ }^{22}$ Terdapat penurunan gejala gatal sebesar $70 \%$ yang terlihat pada minggu ke-2 dan bertahan hingga minggu ke-32. ${ }^{22}$ Selain itu, perbaikan skor gatal berkorelasi signifikan dengan Dermatology Life Quality Index (DLQI) yang terlihat pada minggu ke-16 dan ke-32.22,25 Efek samping yang dilaporkan yaitu nausea, vomitus, nyeri abdomen, dispepsia, serta diare. ${ }^{26}$

\section{Antagonis Interleukin}

Interleukin berperan dalam mediasi respons imun dan inflamasi. Terapi biologik yang memiliki peran untuk tata laksana pruritus di antaranya yaitu antagonis IL-4, IL-13, IL-31, dan IL-17.

\section{a. Dupilumab (LoE 1 dan 4)}

Dupilumab adalah antibodi monoklonal dengan target subunit IL-4R $\alpha{ }^{10,14}$ Dupilumab mencegah ikatan sitokin IL-4 dan IL-13 pada reseptor sehingga terjadi penghambatan respon inflamasi. ${ }^{10}$ Berdasarkan telaah kritis, pada pasien dermatitis atopik sedang-berat, dupilumab $300 \mathrm{mg}$ per 2 minggu memiliki efikasi tinggi terhadap perbaikan gejala gatal, klinis, serta kualitas hidup pasien dalam 4 bulan awal dibandingkan dengan plasebo. ${ }^{21}$ Didapatkan perbaikan signifikan dari Peak Pruritus Numerical Rating Scale (PP-NRS) secara cepat yang bertahan hingga satu tahun. ${ }^{27}$ Beberapa laporan kasus telah melaporkan penggunaan dupilumab bermanfaat pada prurigo nodularis, chronic pruritus of unknown origin (CPUO), pruritus uremikum, pruritus akibat keganasan, dan pemfigoid bulosa. ${ }^{10,14}$ Efek samping meliputi reaksi pada lokasi penyuntikan dan konjungtivitis. ${ }^{16}$

\section{b. Lebrikizumab dan Tralokinumab (LoE 2)}

Yang termasuk dalam antibodi monoklonal anti-IL-13 adalah lebrikizumab dan tralokinumab. Pada uji klinis fase $2 \mathrm{~b}$, injeksi lebrikizumab $250 \mathrm{mg}$ per 2 minggu pada pasien dermatitis atopik menunjukkan perbaikan skor NRS pruritus yang paling besar
(70\%) yang terlihat dalam dua hari hingga hari ke-16. ${ }^{14,28}$ Efek samping yang dilaporkan yaitu reaksi pada tempat penyuntikan, infeksi saluran napas atas, nasofaringitis, nyeri kepala, infeksi virus herpes, kelelahan, dan konjungtivitis. $^{28}$ Pada uji klinis fase 3, tralokinumab $300 \mathrm{mg}$ per 2 minggu secara subkutan pada pasien dermatitis atopik dapat memperbaiki gejala klinis serta menurunkan rerata NRS secara signifikan sebesar 20-25\% pada minggu ke-16 dibandingkan dengan plasebo. ${ }^{29}$

\section{c. Nemolizumab (LoE 2)}

Nemolizumab merupakan antibodi monoklonal anti-IL-31-RA. ${ }^{14}$ Peningkatan ekspresi IL-31 ditemukan pada kulit pasien dengan dermatitis atopik dan prurigo nodularis. ${ }^{14}$ Pada uji klinis fase 2 didapatkan penurunan signifikan VAS gatal sebesar $63,1 \%$ pada dermatitis atopik ringan-sedang dan perbaikan NRS sebesar 53\% di minggu ke4 pada prurigo nodularis sedang-berat. ${ }^{14} \mathrm{Pada}$ uji klinis fase 3, kombinasi nemolizumab 60 mg subkutan per 4 minggu dan terapi topikal menunjukkan perbedaan signifikan dalam penurunan rata-rata VAS gatal sebesar $42,8 \%$ dibandingkan kombinasi plasebo dan terapi topikal $(21,5 \%)$ pada dermatitis atopik. ${ }^{30}$

\section{d. Secukinumab dan Ixekizumab (LoE 1)}

Secukinumab dan ixekozumab adalah antibodi monoklonal anti-IL-17A yang secara selektif berikatan dan menetralkan IL-17A. $^{10}$ Berdasarkan meta-analisis, kedua terapi tersebut secara signifikan mengurangi pruritus pada psoriasis tipe plak dibandingkan dengan plasebo (mean difference -4,52; $\mathrm{p}<0,001$ ). ${ }^{22}$ Secukinumab 150-300 mg subkutan per minggu menunjukkan perbaikan VAS gatal secara signifikan dibandingkan dengan plasebo dan etarnercept. ${ }^{22,31}$ Perbaikan gejala gatal lebih besar terlihat pada grup yang mendapat secukinumab $300 \mathrm{mg}$ per minggu. ${ }^{22,31}$ Ixekizumab $80 \mathrm{mg}$ per 2 minggu subkutan menunjukkan penurunan signifikan VAS gatal dan NRS dibandingkan plasebo dan etarnercept. $^{22,32}$ Efek samping berupa peningkatan risiko infeksi kandida. ${ }^{16}$

\section{Inhibitor Janus Kinase}

Inhibitor janus kinase (JAK) merupakan small molecules yang secara selektif menargetkan beberapa jalur sinyal sitokin sekaligus untuk 
menimbulkan efek antiinflamasi. ${ }^{33}$ Inhibitor JAK memblok jalur sinyal JAK-STAT yang berperan pada transduksi sinyal sitokin dan faktor pertumbuhan. ${ }^{10}$ Golongan yang termasuk inhibitor JAK adalah tofacitinib, baricitinib, upadacitinib, dan abrocitinib. Efek samping tersering akibat terapi inhibitor JAK yaitu nausea, nasofaringitis, dan infeksi. ${ }^{16,34}$ Selain itu, dilaporkan terdapat kejadian neutropenia dan peningkatan kadar lipid. ${ }^{16}$

\section{a. Tofacitinib (LoE 1) dan Baricitinib (LoE 1-} 2)

Tofacitinib bekerja secara selektif menghambat JAK1 dan JAK3. ${ }^{10,33}$ Obat ini telah diuji dalam dua uji klinis fase 3 dan dilaporkan terdapat perbaikan gejala gatal pada pasien psoriasis. . $^{10,22,35}$ Terjadi penurunan rerata skor gatal secara signifikan pada pasien yang diberikan terapi tofacitinib $2 \mathrm{mg}$ hingga $15 \mathrm{mg}$ dibandingkan plasebo dan etarnercept. ${ }^{22}$ Baricitinib merupakan inhibitor selektif dari JAK1 dan JAK2. ${ }^{33}$ Baricitinib dosis $2 \mathrm{mg}$ hingga $10 \mathrm{mg}$ dapat mengurangi skor rerata NRS di minggu ke-12 secara signifikan dibandingkan plasebo. $^{22}$ Uji klinis fase 2 menunjukkan baricitinib secara signifikan memperbaiki lesi serta mengurangi pruritus pada dermatitis atopik. ${ }^{33}$ Berdasarkan metaanalisis, tofacitinib dan baricitinib secara signifikan menurunkan skor pruritus pada pasien psoriasis dibandingkan dengan plasebo. $^{22}$

\section{b. Upadacitinib dan Abrocitinib (LoE 2)}

Upadacitinib dan abrocitinib secara selektif menginhibisi JAK1. Pada uji klinis fase 2, upadacitinib secara signifikan mengurangi gejala gatal pasien dermatitis atopik dalam satu minggu inisiasi terapi. ${ }^{33}$ Berdasarkan uji klinis fase 3, abrocitinib $100 \mathrm{mg}$ hingga $200 \mathrm{mg}$ tiap hari per oral dibandingkan dengan plasebo secara signifikan dapat menurunkan PP-NRS dari baseline pasien dermatitis atopik derajat sedang-berat dimulai pada 24 jam hingga minggu ke- $12 .{ }^{34}$

\section{Antagonis Imunoglobulin E (LoE 2)}

Golongan yang termasuk dalam antagonis imunoglobulin $\mathrm{E}$ ( $\mathrm{IgE}$ ) adalah omalizumab dan ligelizumab. Omalizumab adalah antibodi monoklonal anti-IgE yang memblokir ikatan IgE dengan reseptor FceRI sehingga mencegah aktivasi sel mast dan basofil. ${ }^{14}$ Omalizumab juga dapat mengurangi kadar IgE yang bersirkulasi dan mengurangi ekspresi FceRI. ${ }^{14}$ Berdasarkan uji klinis fase 3, omalizumab secara signifikan menurunkan gejala gatal pada pruritus kronik refrakter. ${ }^{14}$ Ligelizumab memiliki afinitas yang lebih tinggi dibandingkan dengan omalizumab dalam berikatan dengan IgE. ${ }^{10,14}$ Pada uji klinis fase 2, ligelizumab menunjukkan efikasi tinggi pada kasus urtikaria (51\%) dibandingkan dengan omalizumab (26\%) di minggu ke-12.

\section{Terapi Pruritus dengan Target Sistem Saraf}

Sistem saraf perifer dan pusat dapat menjadi target terapi pruritus kronik. Strategi pengobatan ini bertujuan untuk mengurangi sensitisasi neural yang berperan penting pada pruritus kronik. Terapi yang menargetkan sistem saraf pusat di antaranya yaitu inhibitor reseptor neurokinin-1, antagonis reseptor $\mu$-opioid/agonis reseptor $\kappa$-opioid, analog asam gama-aminobutirat, dan antidepresan.

\section{Inhibitor Reseptor Neurokinin-1}

Reseptor NK-1 diekspresikan pada ujung serabut saraf dan banyak ditemukan pada sistem saraf pusat. Selain itu, reseptor NK-1 juga diekspresikan pada sel mast, keratinosit, fibroblast, sel endotel, dan jaringan di perifer. ${ }^{9}$ Ikatan antara SP dengan reseptor NK-1 pada keratinosit menstimulasi pelepasan nerve growth factor, interferon- $\gamma$, IL-1 $\beta$, IL-8, dan leukotriene B4. Pada sel mast dan pembuluh darah, SP memicu degranulasi sel mast dan vasodilatasi sehingga terjadi inflamasi neurogenik dengan gambaran klinis berupa eritema, edema, dan pruritus. ${ }^{9}$ Aktivasi reseptor NK-1 dapat berujung pada transduksi sinyal saraf aferen., ${ }^{4,5}$ Beberapa obat yang merupakan inhibitor NK-1 adalah aprepitant, serlopitant, dan tradipitant.

\section{a. Aprepitant (LoE 4)}

Aprepitant mulanya dikembangkan untuk terapi antiemetik yang diinduksi oleh kemoterapi.${ }^{36}$ Obat ini secara selektif berikatan dengan reseptor NK-1 pada sistem saraf pusat. ${ }^{37}$ Beberapa laporan kasus melaporkan bahwa aprepitant per oral dapat mengurangi skor VAS gatal pada pruritus yang refrakter akibat cutaneous $T$-cell lymphoma ${ }^{37}$ Sebagian laporan kasus menggunakan dosis $125 \mathrm{mg}$ pada hari pertama dilanjutkan dengan dosis 80 mg. Studi lainnya menggunakan dosis $80 \mathrm{mg}$ per hari. ${ }^{37}$ Efek samping berupa gangguan 
gastrointestinal, malaise, vertigo, dan nyeri kepala. $^{16}$

\section{b. Serlopitant (LoE 2)}

Berbagai uji klinis fase 2 telah memperlihatkan manfaat serlopitant sebagai terapi pruritus kronik. Terjadi penurunan signifikan rerata skor VAS dari baseline pada kelompok yang mendapat serlopitant $1 \mathrm{mg}$ per hari atau $5 \mathrm{mg}$ per hari dibandingkan dengan plasebo pada pruritus kronik refrakter. Pada pruritus akibat prurigo nodularis, terdapat penurunan skor VAS dari 7,9 menjadi 4,4 pada minggu ke- $8 .{ }^{37}$ Namun, uji klinis fase 3 menunjukkan hasil yang tidak memenuhi endpoint primer. ${ }^{14} \mathrm{Pada}$ psoriasis tipe plak dengan pruritus berat, serlopitant $5 \mathrm{mg}$ secara signifikan menurunkan Worst Itch Numerical Rating Scale (WI-NRS) sebesar 33,3\% di minggu ke-8. ${ }^{36,38}$ Serlopitant $5 \mathrm{mg}$ per hari dapat menurunkan VAS gatal dan NRS di minggu ke-6 pada pasien dengan CPUO, namun kepastian dari bukti tersebut dikategorikan rendah. ${ }^{39}$ Efek samping obat yang dilaporkan yaitu nasofaringitis, diare, nyeri kepala dan kelelahan. ${ }^{37}$

\section{c. Tradipitant (LoE 2)}

Pada uji klinis fase 2, tradipitant terbukti secara signifikan memperbaiki gejala gatal, keparahan penyakit, serta kualitas hidup pasien dengan dermatitis atopik. Namun, uji klinis fase 3 yang dilaksanakan selama 8 minggu menunjukkan bahwa penurunan WI-NRS pada kelompok pasien yang mendapatkan tradipitant $85 \mathrm{mg} 2$ kali sehari per oral tidak berbeda bermakna dibandingkan dengan plasebo. $^{37}$ Meskipun demikian, analisis subgrup menunjukkan sebanyak $70 \%$ pasien dengan dermatitis atopik derajat ringan terjadi perbaikan WI-NRS. ${ }^{14,37}$

\section{Antagonis Reseptor M-Opioid dan Agonis Reseptor K-Opioid}

Opioid secara umum digunakan sebagai antinyeri, namun saat ini terbukti berperan dalam tata laksana pruritus. Reseptor $\mu-, \kappa-$, dan $\delta$-opioid dapat ditemukan sepanjang susunan saraf pusat dan perifer termasuk pada serabut saraf di kulit. ${ }^{10}$ Reseptor opioid yang berperan pada patofisiologi pruritus adalah reseptor $\mu$-opioid dan $\kappa$-opioid. Aktivasi reseptor $\kappa$-opioid menyebabkan inhibisi transmisi kimiawi sehingga menghambat sinyal gatal. ${ }^{4}$ Sebaliknya, aktivasi dari reseptor $\mu$-opioid memicu gatal. ${ }^{4,11}$

\section{a. Antagonis Reseptor $\mu$-Opioid (LoE 1)}

Obat golongan antagonis reseptor $\mu$-opioid yang berperan pada pruritus adalah naloxone dan naltrexone. Naloxone dosis 1,6 mg per jam selama 4 jam memberikan perbaikan sempurna pada CPUO. ${ }^{39}$ Naltrexone $25 \mathrm{mg}$ hingga $50 \mathrm{mg}$ per hari dilaporkan efektif untuk pruritus kronik pada dermatitis atopik dan pruritus kolestasis. ${ }^{40}$ Efek samping berupa nausea, vomitus, diare, pusing, nyeri kepala, serta malaise. ${ }^{16,41}$

\section{b. Agonis Reseptor K-Opioid (LoE 1-2)}

Golongan agonis reseptor $\kappa$-opioid adalah nalfurafine. Berdasarkan telaah sistematik, nalfurafine $5 \mu \mathrm{g}$ atau $2,5 \mu \mathrm{g}$ per hari secara efektif menurunkan gejala pruritus uremikum. ${ }^{41-43}$ Pada uji klinis fase 3, pasien pruritus kolestasis refrakter yang mendapat nalfurafine $2,5 \mu \mathrm{g}$ dan $5 \mu \mathrm{g}$ per hari secara oral terjadi penurunan VAS gatal secara signifikan dibandingkan dengan plasebo. ${ }^{44}$ Efek samping berupa insomnia, somnolen, dan konstipasi. ${ }^{41}$

\section{c. Antagonis $\mu$-Opioid/Agonis $\kappa$-Opioid} [Butorphanol (LoE 4), Nalbuphine (LoE 2)] Obat golongan antagonis $\mu$-opioid sekaligus agonis א-opioid adalah butorphanol dan nalbuphine. ${ }^{10}$ Butorphanol diberikan melalui rute intranasal dan memiliki onset kerja cepat. ${ }^{10}$ Berdasarkan laporan kasus, lima dari delapan pasien pruritus kolestasis dilaporkan mengalami penurunan VAS gatal setelah terapi dengan butorphanol. ${ }^{45}$ Nalbuphine merupakan pengobatan baru yang saat ini masih dalam uji klinis. Dilaporkan bahwa nalbuphine memiliki efektivitas yang baik pada prurigo nodularis pada uji klinis fase 2. ${ }^{10,46}$ Efek samping berupa pusing, somnolen, nausea, dan vomitus. ${ }^{16}$

\section{Analog Asam Aminobutirat (LoE 1)}

Gabapentin dan pregabalin adalah analog gamma-aminobutyric acid (GABA). Kedua obat tersebut bekerja dengan cara memengaruhi pintu voltase kanal kalsium pada sistem saraf pusat dan dapat menghambat pelepasan neurotransmiter. ${ }^{43}$ Berdasarkan telaah sistematis, gabapentin atau pregabalin dapat menurunkan skor gatal secara signifikan pada pasien pruritus uremikum. ${ }^{42,43}$ Gabapentin dengan dosis $300 \mathrm{mg}$ atau $400 \mathrm{mg} 2$ kali per minggu pada pasien hemodialisis aman dan efektif mengurangi pruritus uremikum. ${ }^{42}$ Tidak ada perbedaan bermakna antara efikasi gabapentin dan pregabalin dalam mengurangi pruritus. ${ }^{42,43}$ 
Pregabalin 75 mg 2 kali per minggu pada pasien hemodialisis memiliki efek signifikan dalam menurunkan pruritus dibandingkan plasebo dan ondansetron. ${ }^{11,47}$ Studi lain didapatkan pregabalin $50 \mathrm{mg}$ selang sehari secara signifikan mengurangi pruritus pada pasien hemodialisis. ${ }^{11,48}$ Pada pruritus akibat prurigo nodularis, pregabalin $75 \mathrm{mg}$ per hari memberikan respons sempurna dalam 3 bulan terapi. ${ }^{19}$ Efek samping gabapentin dan pregabalin berupa somnolen, pusing, peningkatan nafsu makan, berat badan meningkat, serta edema perifer. $^{16}$

\section{Antidepresan}

Antidepresan dapat memengaruhi kadar serotonin dan histamin sehingga direkomendasikan untuk tata laksana pruritus kronik yang tidak responsif dengan terapi lain. ${ }^{11,49}$ Antidepresan yang berperan pada tata laksana pruritus terdiri atas serotonin reuptake inhibitor (SSRI), tricyclic antidepressant (TCA), serta antidepresan atipikal.

\section{a. Serotonin Reuptake Inhibitor (SSRI) (LoE 1)}

Fluvoksamin, paroksetin, dan setralin termasuk dalam golongan SSRI. Fluvoksamin $25 \mathrm{mg}$ hingga $150 \mathrm{mg}$ per hari menurunkan skor VAS gatal pada pruritus refrakter sebesar $3,2 \pm 2,7$ dalam waktu 21,5 minggu. ${ }^{49}$ Paroksetin $20 \mathrm{mg}$ hingga $40 \mathrm{mg}$ per hari dapat memperbaiki gejala pruritus pada keganasan, polisitemia vera, serta CPUO. ${ }^{4,11,49}$ Setralin 75 mg hingga $100 \mathrm{mg}$ per hari dapat menurunkan skor VAS gatal menjadi 1,86 pada pruritus kolestasis. $^{49}$ Uji acak terkontrol membandingkan setralin $50 \mathrm{mg} 2$ kali sehari dengan plasebo pada pasien hemodialisis dilaporkan penurunan skor VAS gatal pada kedua grup dengan penurunan lebih banyak pada grup intervensi. ${ }^{11,43,50}$ Efek samping SSRI berupa rasa kantuk, vertigo, nausea, malaise, nyeri kepala, kenaikan berat badan, dan disfungsi seksual. ${ }^{16}$

\section{b. Tricyclic Antidepressant (TCA) (LoE 1)}

Doksepin dan amitriplin termasuk dalam golongan TCA. Pemberian doksepin $10 \mathrm{mg}$ dua kali sehari secara signifikan memperbaiki pruritus uremikum pada $58,3 \%$ subjek dibandingkan dengan plasebo. ${ }^{42,49}$ Amitriptilin dapat meringankan gatal pada pruritus brachioradial, liken amiloidosis, pruritus uremikum, notalgia paresthetica, pruritus pascastroke, dan prurigo nodularis. ${ }^{19,49}$ Doksepin $25 \mathrm{mg}$ hingga $50 \mathrm{mg}$ per hari dan amitriptilin $25 \mathrm{mg}$ hingga $50 \mathrm{mg}$ per hari direkomendasikan pada pasien pruritus akibat kolestasis atau gagal ginjal kronik. ${ }^{11}$ Efek samping TCA meliputi efek sedasi, hipotensi ortostatik, aritmia, dan efek antikolinergik contohnya pusing, pandangan buram, dan mulut kering. ${ }^{16}$

\section{c. Antidepresan Atipikal (LoE 1)}

Mirtazapin merupakan golongan antidepresan atipikal. Obat ini dapat mencegah pruritus sekunder akibat penggunaan morfin intratekal, menurunkan gejala gatal pada penyakit inflamasi kulit, dan pruritus paraneoplastik. ${ }^{49}$ Mirtazapin dosis $15 \mathrm{mg}$ hingga $30 \mathrm{mg}$ direkomendasikan untuk pruritus akibat keganasan. ${ }^{11}$ Efek samping meliputi peningkatan nafsu makan, peningkatan berat badan, hiperkolesterolemia, pusing, dan efek sedasi. ${ }^{16}$

\section{Fototerapi (LoE 1-2)}

Fototerapi dengan ultraviolet A (UVA) atau ultraviolet B (UVB) direkomendasikan untuk pruritus kronik yang refrakter pada penyakit inflamasi kulit, limfoma kutis, pruritus akibat penyakit sistemik, maupun pada pruritus aquagenik. ${ }^{11}$ Berdasarkan telaah sistematis, terjadi perbaikan gejala gatal secara signifikan pada $70 \%$ pasien psoriasis yang diterapi menggunakan UVB. ${ }^{22}$ Uji acak terkontrol terhadap pasien dermatitis atopik didapatkan penurunan gejala gatal pada $90 \%$ pasien yang diterapi menggunakan NB-UVB dibandingkan dengan UVA. ${ }^{23}$ Hasil dari telaah sistematis didapatkan fototerapi pada kasus pruritus uremikum menggunakan NB-UVB dibandingkan UVA dapat menurunkan skor VAS gatal namun hasil tidak berbeda bermakna antara kedua kelompok. ${ }^{43}$ Pada pruritus kronis, narrowband ultraviolet $B$ (NB-UVB) lebih dipilih karena efektivitas yang baik, tersedia secara luas, memiliki efek eritemogenik yang lebih rendah, serta durasi yang lebih singkat. ${ }^{11,51}$

Radiasi UVA (320 nm hingga $400 \mathrm{~nm}$ ) atau UVB (290 nm hingga $320 \mathrm{~nm}$ ) dapat menginduksi apoptosis sel keratinosit, sel T efektor, sel mast, dan sel Langerhans. ${ }^{11,51}$ Apoptosis terjadi akibat peningkatan reactive oxygen species, kerusakan DNA, dan peningkatan regulasi fas ligan. ${ }^{51}$ Selain itu, terjadi penurunan degranulasi sel mast dan sitokin pro-inflamasi, serta terjadi modulasi sistem saraf. $^{51,52}$ Fototerapi dapat diberikan secara kombinasi dengan terapi topikal atau sistemik. Umumnya dengan frekuensi 2 hingga 3 kali seminggu. ${ }^{51}$ Efek samping meliputi penuaan kulit, 
eritema, kulit terbakar, gangguan pigmentasi, dan fotosensitivitas. ${ }^{16,51,53}$

\section{Terapi Potensial Lain}

Autotaxin merupakan enzim fosfodiesterase yang mengubah lysophosphatidylcholine menjadi lysophosphatidic acid (LPA). ${ }^{5}$ Kadar autotaxin dan LPA meningkat pada pasien kolestasis. ${ }^{54}$ Antagonis reseptor LPA dan inhibitor autotaxin dapat menjadi terapi potensial untuk pruritus kronis akibat kolestasis. ${ }^{5}$ Terapi yang menargetkan $\mathrm{Na}_{\mathrm{v}} 1.7$ juga memiliki kemungkinan untuk dikembangkan sebagai terapi pruritus. Diketahui bahwa $\mathrm{Na}_{\mathrm{v}} 1.7$ berperan pada jalur sinyal pruritus dengan memicu potensial aksi. ${ }^{5}$ Antibodi monoklonal terhadap $\mathrm{Na}_{\mathrm{v}} 1.7$ dilaporkan berhasil mengurangi pruritus akut dan kronik pada mencit. ${ }^{4,10}$

\section{Tata Laksana Pruritus pada Populasi Geriatri}

Secara umum, geriatri memiliki beragam komorbiditas dan mengonsumsi berbagai obat sehingga rentan terjadi efek samping dan interaksi obat. ${ }^{55}$ Kulit kering merupakan faktor mayor yang berkontribusi terhadap pruritus kronik pada geriatri. ${ }^{53}$ Aplikasi pembersih non-iritatif, penggunaan pelembap yang mengandung humektan atau bersifat oklusif, serta menghindari bahan yang dapat mencetuskan gatal merupakan strategi yang paling efektif untuk menjaga integritas sawar kulit dan mencegah terjadinya pruritus. ${ }^{11,53,56}$

Golongan AH1 generasi pertama bersifat lipofilik sehingga dapat melewati sawar darah otak dan menimbulkan efek sedasi dan antikolinergik kuat. ${ }^{55,56}$ Oleh sebab itu, golongan obat tersebut tidak direkomendasikan pada geriatri. Golongan AH1 generasi kedua lebih dipilih karena efek samping yang lebih minimal. ${ }^{53,55}$ Penggunaan kortikosteroid sistemik yang dikombinasikan dengan obat antiinflamasi non-steroid (OAINS) harus dihindari karena dapat meningkatkan risiko ulkus peptikum dan perdarahan saluran cerna. ${ }^{57}$

Penggunaan imunosupresan perlu diwaspadai karena dapat terjadi toksisitas maupun interaksi obat. ${ }^{53}$ Siklosporin mempunyai efek samping berupa peningkatan tekanan darah, nefrotoksik, dan peningkatan risiko infeksi sehingga tidak disarankan pada geriatri. ${ }^{57}$ Dosis rendah dari MTX dapat digunakan untuk geriatri. ${ }^{57}$ Berdasarkan telaah kritis, terapi biologik untuk pasien geriatri memiliki efikasi yang sama seperti dengan populasi dewasa. ${ }^{58}$ Efek samping dan laju infeksi juga memiliki frekuensi yang serupa pada kedua grup, namun efek samping berat lebih sering terjadi pada usia lanjut. ${ }^{58}$

Gabapentin dan pregabalin dapat mencetuskan efek sedasi, nausea, dan ataksia sehingga pada geriatri disarankan menggunakan dosis minimal dan dititrasi secara perlahan. ${ }^{11,55,57}$ Dosis gabapentin dapat dimulai dari $100 \mathrm{mg}$ hingga 300 $\mathrm{mg}$ per hari, sedangkan pregabalin $25 \mathrm{mg}$ hingga $75 \mathrm{mg}$ per hari, diberikan di malam hari. ${ }^{57}$ Penyesuaian dosis juga perlu dilakukan pada pasien dengan gagal ginjal kronik. ${ }^{11,55}$

Antidepresan golongan SSRI harus dihindari pada geriatri dengan riwayat terjatuh karena dapat meningkatkan risiko fraktur panggul. ${ }^{16}$ Golongan TCA memiliki efek antikolinergik kuat sehingga kurang disarankan pada geriatri. ${ }^{11,57}$ Antidepresan yang dapat dipilih untuk pruritus nokturnal dan pruritus uremikum pada populasi geriatri yaitu golongan antidepresan atipikal (mirtazapin) dengan dosis rendah $(7,5 \mathrm{mg}$ hingga $15 \mathrm{mg}) .^{16,57}$ Antagonis reseptor $\mu$-opioid dan agonis reseptor $\kappa$ opioid dapat mengakibatkan depresi napas, hepatotoksisitas, gejala gastrointestinal, vertigo, dan adiksi. ${ }^{11,55}$

\section{Penutup}

Tata laksana pruritus diberikan secara individual dan perlu mempertimbangkan usia, intensitas gatal, penyakit penyerta, kualitas hidup pasien, serta interaksi dan efek samping obat. Pengetahuan mengenai etiologi dan patofisiologi pruritus dapat membantu klinisi menentukan pengobatan yang tepat. Berbagai tata laksana baru untuk pruritus saat ini banyak dikembangkan dalam uji klinis dan diyakini memiliki prospek yang menjanjikan.

\section{Daftar Pustaka}

1. Stander S. Classification of itch. Curr Probl Dermatol. 2016;50:1-4.

2. Stander S, Weisshaar E, Mettang T, Szepietowski JC, Carstens E, Ikoma A, dkk. Clinical classification of itch: A position paper of the international forum for the study of itch. Acta Derm Venereol. 2007;87(4):291-4.

3. Mollanazar NK, Koch SD, Yosipovitch G. Epidemiology of chronic pruritus: Where have we been and where are we going? Curr Derm Rep. 2015;4(1):20-9.

4. Golpanian RS, Yosipovitch G. Current and emerging systemic treatments targeting the 
neural system for chronic pruritus. Expert Opin Pharmacother. 2020;21(13):1629-36.

5. Yosipovitch G, Rosen JD, Hashimoto T. Itch: From mechanism to (novel) therapeutic approaches. J Allergy Clin Immunol. 2018;142(5):1375-90.

6. Mollanazar NK, Smith PK, Yosipovitch G. Mediators of chronic pruritus in atopic dermatitis: Getting the itch out? Clin Rev Allergy Immunol. 2016;51(3):263-92.

7. Stander S, Pereira MP, Luger TA. Neurobiology of the skin. Dalam: Kang S, Amagai M, Bruckner AL, Enk AH, Margolis DJ, McMichael AJ, Orringer, penyunting. Fitzpatrick's dermatology. Edisi ke-9. New York: McGraw-Hill; 2019. h. 351-61.

8. Song J, Xian D, Yang L, Xiong X, Lai R, Zhong J. Pruritus: Progress toward pathogenesis and treatment. Biomed Res Int. 2018:1-12.

9. Stander S, Luger TA. Nk-1 antagonists and itch. Handb Exp Pharmacol. 2015;226:237-55.

10. Fowler E, Yosipovitch G. A new generation of treatments for itch. Acta Derm Venereol. 2020 7;100(2):adv00027.

11. Weisshaar E, Szepietowski JC, Dalgard FJ, Garcovich S, Gieler U, Gimenez-Arnau AM, dkk. European s2k guideline on chronic pruritus. Acta Derm Venereol. 2019;99(5):469-506.

12. Nowak DA, Yeung J. Diagnosis and treatment of pruritus. Can Fam Physician. 2017;63(12):918-24.

13. Phinyo $\mathrm{P}$, Koompawichit $\mathrm{P}$, Nochaiwong $\mathrm{S}$, Tovanabutra N, Chiewchanvit S, Chuamanochan M. Comparative efficacy and acceptability of licensed dose secondgeneration antihistamines in chronic spontaneous urticaria: A network metaanalysis. J Allergy Clin Immunol Pract. 2021;9(2):956-70 e57.

14. Erickson S, Heul AV, Kim BS. New and emerging treatments for inflammatory itch. Ann Allergy Asthma Immunol. 2021;126(1):13-20.

15. Thomas J, Saple DG, Jerajani HR, Netha NRG, Rangasamy DU, Shaikh R, dkk. Real-world, non-interventional, observational study of hydroxyzine hydrochloride in chronic pruritus: A prospective, non-comparative study. Dermatol Ther (Heidelb). 2019;9(2):299-308.

16. Fourzali K, Yosipovitch G. Safety considerations when using drugs to treat pruritus. Expert Opin Drug Saf. 2020;19(4):467-77.
17. Kabashima $\mathrm{K}$, Irie $\mathrm{H}$. Interleukin-31 as a clinical target for pruritus treatment. Front Med. 2021;8:638325.

18. Stull C, Grossman S, Yosipovitch G. Current and emerging therapies for itch management in psoriasis. Am J Clin Dermatol. 2016;17(6):617-24.

19. Qureshi AA, Abate LE, Yosipovitch G, Friedman AJ. A systematic review of evidencebased treatments for prurigo nodularis. $\mathrm{J}$ Am Acad Dermatol. 2019;80(3):756-64.

20. Klejtman T, Beylot-Barry M, Joly P, Richard MA, Debarbieux S, Misery L, dkk. Treatment of prurigo with methotrexate: A multicentre retrospective study of 39 cases. J Eur Acad Dermatol Venereol. 2018;32(3):437-40.

21. Drucker AM, Ellis AG, Bohdanowicz M, Mashayekhi S, Yiu ZZN, Rochwerg B, dkk. Systemic immunomodulatory treatments for patients with atopic dermatitis: A systematic review and network meta-analysis. JAMA Dermatol. 2020;156(6):659-67.

22. Therene C, Brenaut E, Barnetche T, Misery L. Efficacy of systemic treatments of psoriasis on pruritus: A systemic literature review and meta-analysis. J Invest Dermatol. 2018;138(1):38-45.

23. Pavlis J, Yosipovitch G. Management of itch in atopic dermatitis. Am J Clin Dermatol. 2018;19(3):319-32.

24. Maley A, Swerlick RA. Azathioprine treatment of intractable pruritus: A retrospective review. J Am Acad Dermatol. 2015;73(3):439-43.

25. Sobell JM, Foley P, Toth D, Mrowietz U, Girolomoni G, Goncalves J, dkk. Effects of apremilast on pruritus and skin discomfort/pain correlate with improvements in quality of life in patients with moderate to severe plaque psoriasis. Acta Derm Venereol. 2016;96(4):514-20.

26. Zebda R, Paller AS. Phosphodiesterase 4 inhibitors. J Am Acad Dermatol. 2018;78(3 Suppl 1):S43-52.

27. Silverberg JI, Yosipovitch G, Simpson EL, Kim BS, Wu JJ, Eckert L, dkk. Dupilumab treatment results in early and sustained improvements in itch in adolescents and adults with moderate to severe atopic dermatitis: Analysis of the randomized phase 3 studies solo 1 and solo 2, ad adol, and chronos. J Am Acad Dermatol. 2020;82(6):1328-36.

28. Guttman-Yassky E, Blauvelt A, Eichenfield LF, Paller AS, Armstrong AW, Drew J, dkk. Efficacy and safety of lebrikizumab, a highaffinity interleukin 13 inhibitor, in adults with 
moderate to severe atopic dermatitis: A phase $2 \mathrm{~b}$ randomized clinical trial. JAMA Dermatol. 2020;156(4):411-20.

29. Wollenberg A, Blauvelt A, Guttman-Yassky E, Worm M, Lynde C, Lacour JP, dkk. Tralokinumab for moderate-to-severe atopic dermatitis: Results from two 52-week, randomized, double-blind, multicentre, placebo-controlled phase iii trials (ecztra 1 and ecztra 2). Br J Dermatol. 2020;184(3):437-49.

30. Kabashima K, Matsumura T, Komazaki H, Kawashima M, Nemolizumab JPSG. Trial of nemolizumab and topical agents for atopic dermatitis with pruritus. N Engl J Med. 2020;383(2):141-50.

31. Langley RG, Elewski BE, Lebwohl M, Reich $\mathrm{K}$, Griffiths CE, Papp K, dkk. Secukinumab in plaque psoriasis--results of two phase 3 trials. N Engl J Med. 2014;371(4):326-38.

32. Griffiths CE, Reich K, Lebwohl M, van de Kerkhof P, Paul C, Menter A, dkk. Comparison of ixekizumab with etanercept or placebo in moderate-to-severe psoriasis (uncover-2 and uncover-3): Results from two phase 3 randomised trials. Lancet. 2015;386(9993):541-51.

33. Erickson S, Nahmias Z, Rosman IS, Kim BS. Immunomodulating agents as antipruritics. Dermatol Clin. 2018;36(3):1-10.

34. Silverberg JI, Simpson EL, Thyssen JP, Gooderham M, Chan G, Feeney C, dkk. Efficacy and safety of abrocitinib in patients with moderate-to-severe atopic dermatitis: A randomized clinical trial. JAMA Dermatol. 2020;156(8):863-73.

35. Feldman SR, Thaci D, Gooderham M, Augustin M, de la Cruz C, Mallbris L, dkk. Tofacitinib improves pruritus and healthrelated quality of life up to 52 weeks: Results from 2 randomized phase iii trials in patients with moderate to severe plaque psoriasis. J Am Acad Dermatol. 2016;75(6):1162-70 e3.

36. Pojawa-Golab M, Jaworecka K, Reich A. Nk1 receptor antagonists and pruritus: Review of current literature. Dermatol Ther (Heidelb). 2019;9(3):391-405.

37. Alam M, Buddenkotte J, Ahmad F, Steinhoff M. Neurokinin 1 receptor antagonists for pruritus. Drugs. 2021;81:621-34.

38. Pariser DM, Bagel J, Lebwohl M, Yosipovitch G, Chien E, Spellman MC. Serlopitant for psoriatic pruritus: A phase 2 randomized, double-blind, placebo-controlled clinical trial. J Am Acad Dermatol. 2020;82(6):1314-20.
39. Andrade A, Kuah CY, Martin-Lopez JE, Chua S, Shpadaruk V, Sanclemente G, dkk. Interventions for chronic pruritus of unknown origin. Cochrane Database Syst Rev. 2020;1:CD013128.

40. Ekelem C, Juhasz M, Khera P, Mesinkovska NA. Utility of naltrexone treatment for chronic inflammatory dermatologic conditions: A systematic review. JAMA Dermatol. 2019;155(2):229-36.

41. Jaiswal D, Uzans D, Hayden J, Kiberd BA, Tennankore KK. Targeting the opioid pathway for uremic pruritus: A systematic review and meta-analysis. Can J Kidney Health Dis. 2016;3:1-9.

42. Hercz D, Jiang SH, Webster AC. Interventions for itch in people with advanced chronic kidney disease. Cochrane Database Syst Rev. 2020;12:1-172.

43. Malekmakan L, Tadayon T, Pakfetrat M, Mansourian A, Zareei N. Treatments of uremic pruritus: A systematic review. Dermatol Ther. 2018;31(5):e12683.

44. Kumada H, Miyakawa H, Muramatsu T, Ando $\mathrm{N}$, Oh T, Takamori K, dkk. Efficacy of nalfurafine hydrochloride in patients with chronic liver disease with refractory pruritus: A randomized, double-blind trial. Hepatol Res. 2017;47(10):972-82.

45. Golpanian RS, Yosipovitch G, Levy C. Use of butorphanol as treatment for cholestatic itch. Dig Dis Sci. 2020:1-7.

46. Mathur VS, Kumar J, Crawford PW, Hait H, Sciascia T, Investigators TRS. A multicenter, randomized, double-blind, placebo-controlled trial of nalbuphine er tablets for uremic pruritus. Am J Nephrol. 2017;46(6):450-8.

47. Yue J, Jiao S, Xiao Y, Ren W, Zhao T, Meng J. Comparison of pregabalin with ondansetron in treatment of uraemic pruritus in dialysis patients: A prospective, randomized, doubleblind study. Int Urol Nephrol. 2015;47(1):1617.

48. Foroutan N, Etminan A, Nikvarz N, Shojai Shahrokh Abadi M. Comparison of pregabalin with doxepin in the management of uremic pruritus: A randomized single blind clinical trial. Hemodial Int. 2017;21(1):63-71.

49. Kouwenhoven TA, van de Kerkhof PCM, Kamsteeg M. Use of oral antidepressants in patients with chronic pruritus: A systematic review. J Am Acad Dermatol. 2017;77(6):1068-73 e7.

50. Pakfetrat M, Malekmakan L, Hashemi N, Tadayon T. Sertraline can reduce uremic 
pruritus in hemodialysis patient: A double blind randomized clinical trial from southern iran. Hemodial Int. 2018;22(1):103-9.

51. Zhong CS, Elmariah SB. Phototherapy for itch. Dermatol Clin. 2020;38(1):145-55.

52. Legat FJ. The antipruritic effect of phototherapy. Front Med. 2018;5:333.

53. Pereira MP, Stander S. Therapy for pruritus in the elderly: A review of treatment developments. Expert Opin Pharmacother. 2018;19(5):443-50.

54. Patel SP, Vasavda C, Ho B, Meixiong J, Dong $\mathrm{X}$, Kwatra SG. Cholestatic pruritus: Emerging mechanisms and therapeutics. J Am Acad Dermatol. 2019;81(6):1371-8.
55. Cao T, Tey HL, Yosipovitch G. Chronic pruritus in the geriatric population. Dermatol Clin. 2018;36(3):199-211.

56. Chung BY, Um JY, Kim JC, Kang SY, Park $\mathrm{CW}$, Kim HO. Pathophysiology and treatment of pruritus in elderly. Int $\mathrm{J}$ Mol Sci. 2020;22(1):1-12.

57. Fourzali KM, Yosipovitch G. Management of itch in the elderly: A review. Dermatol Ther (Heidelb). 2019;9(4):639-53.

58. Sandhu VK, Ighani A, Fleming P, Lynde CW. Biologic treatment in elderly patients with psoriasis: A systematic review. J Cutan Med Surg. 2020;24(2):174-186. 